\title{
Evaluation of pre-germination treatments on four native species of the High Andean forest
}

\author{
Evaluación de métodos pre-germinativos de cuatro especies nativas \\ del bosque Alto Andino
}

Pedro Pablo Bacca Acosta1; Diana Lucía Burbano Martínez²; Angélica Sofía Moreno Muñoz ${ }^{3}$

\begin{tabular}{l}
\hline \multicolumn{2}{c}{ ARTICLE DATA } \\
\hline 1. Research. M.Sc.. Corporación Colombiana de \\
Investigación Agropecuaria - AGROSAVIA. Centro \\
de Investigación el Mira, Tumaco, Colombia, \\
pbacca@agrosavia.co \\
2. Research. Biologist. Fundación Biofuturo. Pasto, \\
Colombia, dbiologia@gmail.com. \\
3. Agroforestry Engineer. Universidad de Nariño. \\
Pasto, Colombia, sofia94057@hotmail.com.
\end{tabular}

Cite: Bacca, P.; Burbano, D.; Moreno, A. (2020). Evaluation of pre-germination treatments on four native species of the High Andean forest. Revista de Ciencias Agrícolas. 37(1): 80-89.

doi: https://doi.org/10.22267/rcia.203701.130

Received: November 072018.

Accepted: March 152020.

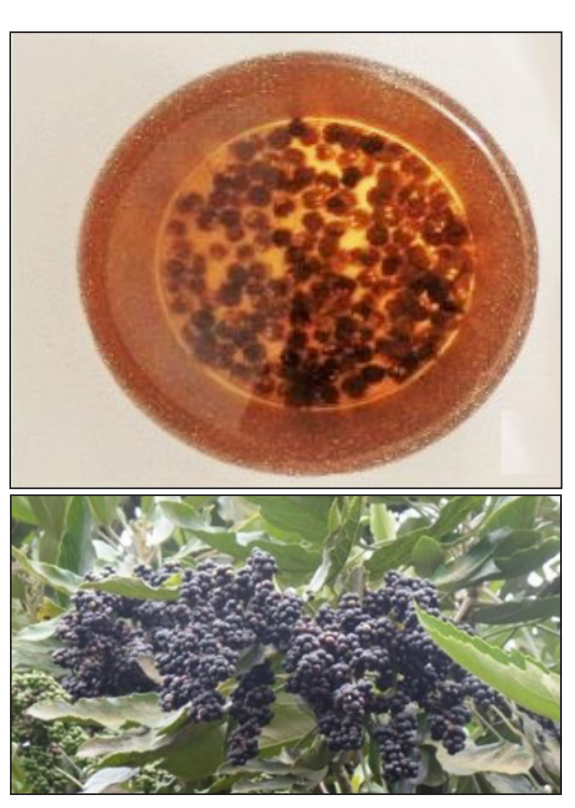

Tournefortia fuliginosa Benth

\section{ABSTRACT}

High Andean forests are strategic ecosystems with high diversity of native and endemic plants; however, these natural ecosystems are affected by agricultural expansion. Knowledge on the propagation of native plants is essential to restore these environments. This research aimed to evaluate germination in the following native species: Viburnum triphyllum Kunt. (Caprifoliaceae), Oreopanax floribundum Kunth, (Araliaceae), Weinmannia tomentosa L.f. (Cunoniaceae), and Tournefortia fuliginosa Benth. (Boraginaceae) in Botana experimental farm of Universidad de Nariño. This study was conducted between October (2016) and February (2017). For each species, an unrestricted randomized split-plot design was established. The main plot included the substrates $(\mathrm{S})$ and the sub-plots included the different pre-germination treatments (PM) with three repetitions. The results showed statistically differences in germination percentage among pre-germination treatments for 0 . floribundum. The highest germination percentage (42\%) for this species was achieved with seed imbibition for 48 hours at $22^{\circ} \mathrm{C}$. Moreover, $W$. tomentosa showed statistical differences for $\mathrm{S}$ and $\mathrm{PM}$, with a germination percentage of $74 \%$ with imbibition for $48 \mathrm{~h}$ at $22^{\circ} \mathrm{C}$ and sand substrate. T. fuliginosa did not show relevant differences; however, it had a germination percentage of $47 \%$. V. triphyllum did not germinate; therefore, further evaluations of pre-germination treatments should be required.

Keywords: Trees; management; propagation; seeds; substrate.

\section{RESUMEN}

Los bosques Alto Andinos son ecosistemas estratégicos que, albergan gran diversidad de plantas nativas y endémicas; sin embargo, la expansión agropecuaria ha afectado estos ecosistemas naturales. Conocer la propagación de plantas nativas para la restauración de estos ambientes es muy importante. Esta investigación tuvo como objetivo evaluar la germinación de las especies; Viburnum triphyllum Kunt. (Caprifoliaceae), Oreopanax floribundum Kunth, (Araliaceae), 
Weinmannia tomentosa L.f. (Cunoniaceae) y Tournefortia fuliginosa Benth. (Boraginaceae) en la Granja Experimental Botana, Universidad de Nariño. El estudio se realizó entre Octubre (2016) y febrero (2017). Para cada especie se estableció un diseño irrestrictamente al zar con distribución de tratamientos en parcelas divididas donde la parcela principal correspondió a los sustratos (S) y la subparcela a los diferentes manejos pre-germinativos (MP) de bloques completos al azar donde, el sustrato (S) fue el factor de bloqueo con cuatro manejos pre-germinativos a la semilla (MP) y los tratamientos resultaron de la combinación de S y MP con tres repeticiones, para evaluar porcentaje de germinación. Los resultados mostraron diferencias estadísticas en los manejos pre-germinativos para O. floribundum; con imbibición por $48 \mathrm{~h}$ a una temperatura de $22^{\circ} \mathrm{C}$ obtiene mejores resultados alcanzando una germinación del $42 \%$. W. tomentosa presentó diferencias significativas en S y tratamientos; con imbibición por $48 \mathrm{~h}$ a una temperatura de $22^{\circ} \mathrm{C}$ con sustrato arena, alcanzó una germinación del 74\%. T. fuliginosa no mostró diferencias significativas, sin embargo, alcanzó el $47 \%$ de germinación. V. triphyllum no presentó germinación, por tanto, se recomienda implementar nuevas evaluaciones de germinación.

Palabras clave: árboles; manejo; propagación; semillas; sustrato.

\section{INTRODUCTION}

High Andean forests are strategic ecosystems with high diversity of native and endemic plants. These forests regulate water interception, store carbon, and increase soil fertility (MancipeMurillo et al., 2018; Melissa and Torres, 2016; Quintero et al., 2017). In Colombia, this natural ecosystem covers $24.9 \%$ of its surface ; however, natural and anthropic factors, such as land use and land use change (LULUFC) exert high pressure on this ecosystem (Cárdenas-Burgos et al., 2019; Quintero et al., 2017).

One of the challenges of ecological restoration is the recovery of this forest ecosystem using native pioneer species that favor the establishment of ombrophytes and contribute to the exchange of soil nutrients (Acero-Nitola and Cortés-Pérez, 2014). Therefore, knowledge of the main soil physical factors and their relationship with water and temperature is essential to efficiently propagate these species (Sánchez et al., 2019). Consequently, the propagation of wild plants, in nurseries using low-cost pre-germination techniques, may constitute a sustainable management method (Aguilar and Vanegas, 2009; Espitia et al., 2016; Sánchez et al., 2015).
The tree species: Viburnum triphyllum Kunt. (Caprifoliaceae), Oreopanax floribundum Kunth. (Araliaceae), Weinmannia tomentosa L.f. (Cunoniaceae), and Tournefortia fuliginosa Benth. (Boraginaceae), commonly known as pelotillo, mano de oso, encenillo, and pundé, respectively, are relevant components for the diversity of the High Andean ecosystem. These native species are valuable for restoration and revegetation processes in forests and water sources due to their morphological, physiological, and ecological characters and cultural importance (Bacca and Burbano, 2018; Hernández-Pineda et al., 2014).

Despite the value of wild species, studies on the germination of native High Andean species are currently scarce (Mancipe-Murillo et al., 2018). Moreover, there is a little knowledge of the effectiveness of pre-germination treatments for plant propagation in restoration projects (Dayrell et al., 2016; Di Sacco et al., 2018; Espitia et al., 2017; Sánchez and Furrazola, 2018; Sánchez et al., 2018a). However, recent researches on native species have been addressed, for instance, the performance of $V$. triphyllum seedlings under two treatments in pasture zones, reporting higher survival rates in the treatment without nutrient amendment. 
This finding demonstrates the establishment of seedlings in degraded sites and eroded soils and reduces nursery costs (Hernández-Pineda et al., 2014). Furthermore, a study on carbon capture of 0 . floribundum was conducted for restoration efforts in La Poma ecological park in Bogotá. The species showed fast growth and capacity to overcome water deficit, since $30 \%$ of the biomass carbon content was present in the root system (Díaz and Velásquez, 2015). Moreover, Bacca and Burbano (2018) assessed the growth of 0 . floribundum seedlings, concluding that this species is suitable for ecological restoration since it grows in areas with agricultural and livestock impacts. In a nursery, Aguilar and Vanegas (2009) evaluated the germination of different native species to generate a source of plant material and baseline knowledge. Among the species studied, V.triphyllum, O.floribundum, and $W$. tomentosa are timber trees used to promote forest restoration, protect water sources and soil quality. Furthermore, propagation of these species is mainly done through the use of seeds, which must be subjected to pre-germination treatments through imbibition for different periods and at variable temperatures. Finally, T. fuliginosa, a fast-growth tree, is use to basin's river protection (Toro, 2010).

On this basis, this study evaluated the germination of 0 . floribundum, W. tomentosa, $T$. fuliginosa, and $V$. triphyllum with different substrates and pre-germination managements in the nursery of Botana experimental farm to contribute knowledge of the propagation of these species that can be replicated by smallscale growers and integrated into restoration processes.

\section{MATERIAL AND METHODS}

Study area. This research was conducted in the nursery of Botana experimental farm of
Universidad de Nariño, located in the foothills of Galeras volcano, Pasto (Nariño) at 2820 masl. at $01^{\circ} 09^{\prime} 40.6^{\prime \prime} \mathrm{N}$ and $77^{\circ} 16^{\prime} 44.6^{\prime \prime} \mathrm{W}$. The locality has an average temperature of $13^{\circ} \mathrm{C}$, an average annual precipitation of $945 \mathrm{~mm}$, and $82 \%$ relative humidity (IDEAM, 2018). This area is classified as a lower montane moist forest (LM-f), according to the Holdridge's life zones system (1990).

Species identification and selection. Species selection was based on cultural, ecological, and/or economic criteria of local growers. Likewise, the selection was also based on the study by Bacca and Burbano (2018) focused on the floristic composition of the High Andean ecosystem, which prioritizes the study of species suitable for ecologic restoration of the High Andean forest in Botana experimental farm.

The following species were selected for this study: O. floribundum, W. tomentosa, T. fuliginosa, and $V$. triphyllum, which belong to the families Araliaceae, Cunoniaceae, Boraginaceae, and Caprifoliaceae, respectively. Particularly, these families are used in the re-establishment of degraded areas, ecological restoration, and revegetation (Bacca and Burbano, 2018; Díaz and Velásquez, 2015; Hernández-Pineda et al., 2014; Toro, 2010). Furthermore, these species are acknowledged by local experts and have a cultural value.

Seed collection. The seeds used in this study were collected between October and November of 2016. The best individuals were identified during forest visits, resulting in the selection of 10 healthy, vigorous, and accessible trees per species. Mature and healthy fruits were collected from the ground or directly from the tree canopy using an extension pole. The fruits were stored in paper bags at room temperature and constant humidity. 
To extract the seeds, fruit processing was performed according to fruit morphology (i.e., fleshy or dry) (Di Sacco et al., 2018; EspitiaCamacho et al. 2018; Moreno and Cuartas, 2015; Torres et al. 2017). 1. Fleshy fruits: V. triphyllum and T. fuliginosa have purple and white round drupe fruits, respectively, at maturity stage. o. floribundum has purple round berry fruits. These fruits were manually opened under water; the seeds were washed and dried on paper at current air temperature. This process was performed immediately after fruit collection to avoid seed fermentation and damage. 2. Dry fruits: $W$. tomentosa has capsules that are easily opened by shaking (Di Sacco et al., 2018).

Seed viability was determined by the floatation technique which consisted of separating and discarding floating seeds. This technique also allowed extracting unwanted particles (Di Sacco et al., 2018; Oliva et al., 2015).

Evaluation of germination. The evaluation began in December 2016 until February 2017. The seeds were subjected to different hydration pre-germination managements associated with fundamental factors such as temperature and imbibition time, which were conducted in a recipient with $400 \mathrm{~mL}$ of water under controlled conditions (Table 1) (Sánchez and Furrazola, 2018). The substrates varied regarding the ratio of sand and soil to obtain differences in filtration and humidity (Table 1). Before the application of the pre-germination management, the substrates were disinfected with boiling water. The seeds were planted in polyethylene bags with dimensions $3.5 \times 6 \times 1 \mathrm{~cm}$ at a depth of three times the seed diameter and watered daily (Aguilar and Vanegas, 2009; Di Sacco et al., 2018; Lazos-Monterrosa et al., 2015).

Experimental design. For each species, a completely randomized design was established with treatments distributed into split-plots. The main plot included the substrates (S) and the sub-plots included the different pre-germination treatments (PM) with three repetitions. The experimental sub-unit consisted of 20 seeds, for a total of 960 seeds per species and 3840 seeds total for the experiment (Di Sacco et al., 2018).

Germination percentage $(\% \mathrm{G})$ (equation 1 ) was assessed to determine the effect of the substrates and seed managements on germination capacity (Lazos-Monterrosa et al., 2015).

$\mathrm{G} \%=\frac{\mathrm{N}^{\circ} \text { of germinated seeds }}{\mathrm{N}^{\circ} \text { of total seeds }} \times 100 \quad$ [Equation 1]

The observations consisted of weekly recordings until the number of germinated seeds was constant. The seeds germinated when the radicle emerged through the seed tegument and appeared on the substrate (Di Sacco et al., 2018; Lazos-Monterrosa et al., 2015; Sánchez et al., 2015).

Table 1. Substrates and pre-germination treatments used to evaluate the germination percentage of four native species.

\begin{tabular}{ll}
\hline Substrate (S) & Pre-germination treatments (PM) \\
\hline S1: soil $(100 \%)$ & PM1: imbibition for $48 \mathrm{~h}-\mathrm{T}^{\circ} 22^{\circ} \mathrm{C}$ \\
S2: sand $(100 \%)$ & PM2: imbibition for $24 \mathrm{~h}-\mathrm{T}^{\circ} 22^{\circ} \mathrm{C}$ \\
S3: soil + sand $(50 \%-50 \%)$ & PM3: imbibition for $5 \mathrm{~min}-\mathrm{T}^{\circ} 80^{\circ} \mathrm{C}$ \\
Control & PM4: without imbibition \\
\hline
\end{tabular}


Statistical analysis. Data was tested for normality using the Shapiro-Wilk test. Additionally, an analysis of variance (ANOVA) was performed, followed by Tukey's multiple comparison test using Infostat@ V.2019 statistical program. Significant values were established at P-values below $0.05(P<0.05)$ (Zar, 2010).

\section{RESULTS AND DISCUSSION}

Germination. Germination of 0 . floribundum was measured at 35 days after sowing in the three substrates. This species showed germination percentages of 25 and 23\% for PM1 in S1 and S3, respectively, and 7\% for PM1 and PM4 in S2 (Figure 1). These findings confirm that morphological seed dormancy occurred in O. floribundum since a minimum of 28 days were required for onset of germination (Sánchez et al., 2019). At 91 days, the final germination percentages were $42 \%$ in S3, 35\% in S1, and $28 \%$ in S2 with PM1.
The analysis of variance did not show statistical differences in the germination percentage $(\% G)$ of 0 . floribundum across substrates $(P<0.4823)$; therefore, these factors do not affectgermination. Conversely, significant differences were found in response to pre-germination managements $(P<0.0193)$. Figure 2 shows that PM1 promoted the best germination percentages compared with the other pre-germination treatments. According to Sánchez et al. (2019), the family Araliaceae requires little sunlight and moist stratification for one or two months to reach $30 \%$ germination. Conversely, this study showed that up to $42 \%$ germination can be obtained by imbibition for 48 hours, while a temperature increase can reduce germination to 7\%; thus, classifying these seeds as sensitive to heat stress. Therefore, if these seeds are left under direct sun exposure during planting, it can hinder their establishment; similar findings were established by Sánchez et al. (2015) in their study using autochthonous species of the same family.

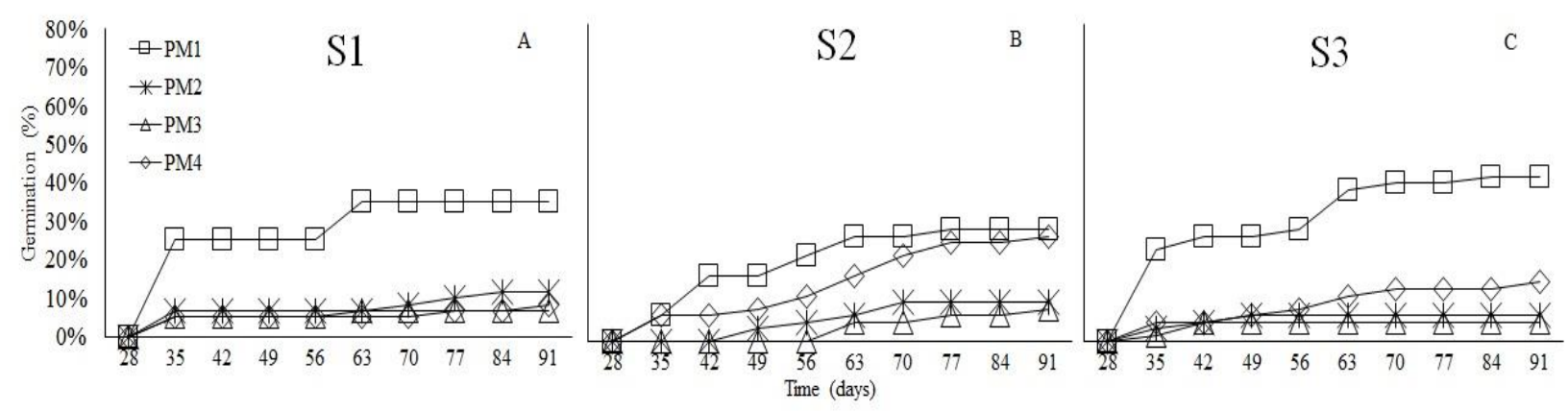

Figure 1. Germination performance of 0. floribundum. A: S1; B: S2; C: S3 with PM1, PM2, PM3, PM4. 


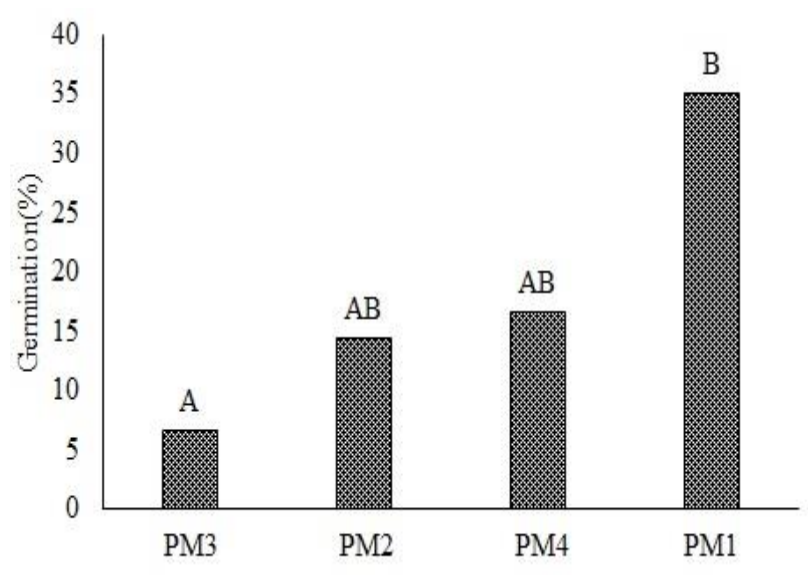

Figure 2. Germination percentage of $O$. floribundum in response to pre-germination treatments PM1, PM2, PM3, PM4. Tukey's multiple comparison test $(P<0.05)$.

The germination in $W$. tomentosa began at 35 days after sowing in the three substrates (Figure x3). During this period, PM2 in S1 reached a germination percentage of $42 \%$, PM1 in S2 achieved 60\% germination, and PM1 in S3 obtained 53\% germination. This study demonstrates that seed dormancy in W. tomentosa is broken by imbibition for $48 \mathrm{~h}$ and sand substrate. Sánchez et al. (2019) mention that the family Cunoniaceae displays physiological dormancy with permeable seed coats and developed embryos (Baskin and Baskin, 2014; Sánchez et al., 2018b).

The analysis of variance did not show statistical differences in the germination percentage $(\% \mathrm{G})$ of $W$. tomentosa in response to pregermination treatments $(P<0.1207)$. However, significant differences in $\% \mathrm{G}$ was observed across substrates $(P<0.0038)$. Figure $4 \mathrm{~A}$ shows that utmost germination percentage $(68 \%)$ was achieved in S3, which showed a percentage of 74\%. Regarding, S2 the highest percentage of germination was reached after 91 days, in all pre-germination treatments, ranging between 61 and 74\% (Figure 4B). These values were higher than those reported by Romero (2015) for the same species, who observed germination percentages up to $45 \%$ in sand substrate. Moreover, Aguilar and Vanegas (2009) suggest an imbibition time of $24 \mathrm{~h}$ on this same substrate. Siura and Moreno (2016) mention that sand substrate can promote germination since it is inert and provides better contact water-seeds; additionally, sand allows water to filter easily, which prevents phytosanitary issues.

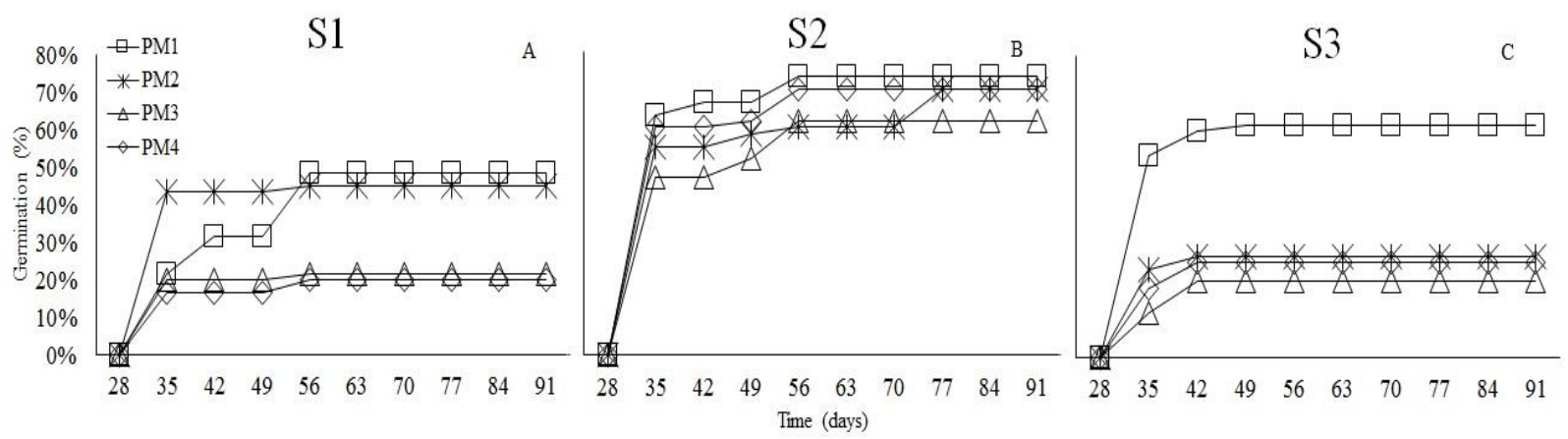

Figure 3. Germination behavior of $W$. tomentosa. A: S1; B: S2; C: S3 with PM1, PM2, PM3, PM4. 

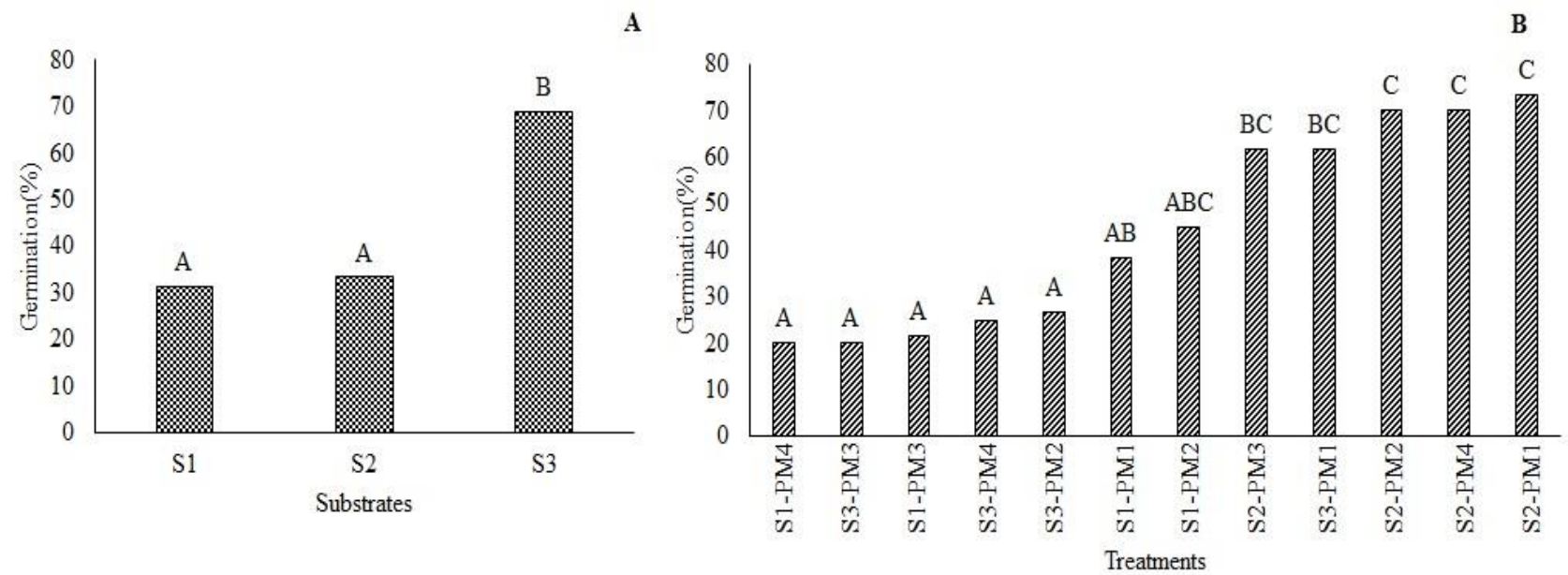

Figure 4. Germination percentage of $W$. tomentosa. A: substrates; S1, S2, S3. B: treatments (S-PM). Means with the same letter are not significantly different from each other $(P<0.05)$.

T. fuliginosa started to germinate at 35 days after sowing (Figure 5). The initial germination percentage was $7 \%$ with $\mathrm{S} 1$ and $\mathrm{S} 3$, and $3 \%$ with S2 using PM1. By the end of the experiment, PM4 reached the highest value $(47 \%)$ in S2, followed by S1 with PM4 (37\%) and S3 with PM2 (33\%).

The analysis of variance showed no statistical differences in the germination percentage $(\% \mathrm{G})$ of $\mathrm{T}$. fuliginosa in response to substrates $(P<0.3261)$ and pre-germination treatments $(P<0.1090)$. Sánchez et al. (2019) state that species of the family Boraginaceae are tolerant to temperatures between 25 and $35^{\circ} \mathrm{C}$; furthermore, to achieve efficient germination, the seeds must be wrapped up in water for $12 \mathrm{~h}$ and scarified to break physiological dormancy. However, according to this research, T. fuliginosa seeds germinate without pre-germination management (47\%), and with imbibition for $24 \mathrm{~h}$ on sand substrate, it reaches a germination of $42 \%$. This can be explained since the species easily adapts to several environments, such as the edges of water bodies with sandy soils. (Sánchez and Furrazola, 2018; Toro, 2010). Moreover, Guerra etal. (2014) mention that sand substrate provides the necessary conditions for germination by avoiding excess of water and fungal growth.

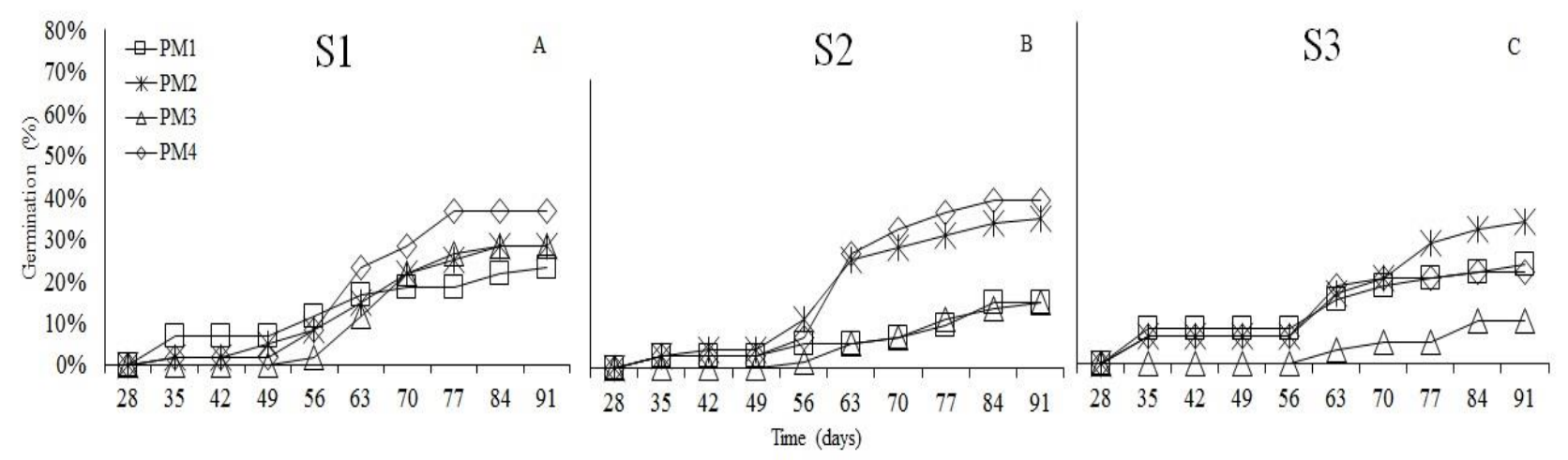

Figure 5. Germination behavior of T. fuliginosa. A: S1; B: S2; C: S3 with PM1, PM2, PM3, PM4. 
Viburnum triphyllum seeds did not respond to the treatments $(0 \% \mathrm{G})$. In this case, imbibition and warm stratification might have inhibited germination. Specifically, the hardness of the seed hull may have caused mechanical resistance to imbibition and embryo emergence. Therefore, different pre-germination treatments should be applied to break seed dormancy in this species. In most tree and shrub species, scarification is recommended to eliminate seed skin impermeability and overcome the physiological component that causes dormancy (Sánchez et al., 2019). Another pre-germination treatment can involve exposure of seeds to thermoperiods that resemble the effect of climate variability, which promotes germination in several species.

Similarly, treatment with sulfuric acid (H2SO4) can be applied to simulate the action of the gastric acid of birds and mammals that disperse this type of seeds, thus, eliminating impermeability and breaking physiological dormancy (AceroNitola and Cortés -Pérez, 2014; Espitia et al., 2016; Sánchez and Furrazola, 2018; Sánchez et al., 2015; Sánchez et al., 2019). Nevertheless, the reproduction of many wild tree species is highly complex since dormancy is a natural survival mechanism and poses a challenge to manipulate germination (Sánchez et al., 2015).

Overall, this study contributes to the scientific knowledge on the germination of e four native species. The germination percentages were highly variable, ranging from 42 to $74 \%$ for 0 . floribundum and $W$. tomentosa, respectively. This variability is likely attributed to morphological and physiological responses of seeds to substrates and pre-germination treatments. Furthermore, the environmental conditions of site and the collection of seeds directly from the wild forest (i.e., without silvicultural management or genetic improvement) can also contribute to this variability (Tomášková et al.,
2014). Mancipe-Murillo et al. (2018) reported different germination percentages, ranging from 25 to $100 \%$, for native species from the High Andean Forest.

Palomeque et al. (2017) explained that low or null germination percentages could be associated with effective pollination, in which the mother tree displays floral asynchrony, or a high percentage of flowers that do not receive pollen, leading to low propagation. Some species have seeds with embryos that are morphologically developed but physiologically immature, which can affect germination capacity (Courtis, 2013); however, dormancy decreases when maturity is reached. Finally, many wild species inhabit extreme environments that affect seed production and cause low viability (BarrettLennard et al., 2016; Dayrell et al., 2016).

\section{CONCLUSIONS}

Germination of 0 . floribundum is affected by the pre-germination treatment. The highest germination percentage (42\%) for this species was achieved with seed imbibition for $48 \mathrm{~h}$ at $22^{\circ} \mathrm{C}$.

Seed propagation of $W$. tomentosa achieved a germination percentage of $74 \%$, with imbibition for $48 \mathrm{~h}$ at $22^{\circ} \mathrm{C}$ and sand substrate. This finding constitutes a propagation alternative for this species.

The treatments and substates used here did not affect the germination of T. fuliginosa; however, germination percentage was $47 \%$.

The substrates and pre-germination treatments applied to $V$. triphyllum did not stimulate seed germination. Therefore, additional research should consider scarification or thermoperiod treatments. 


\section{ACKNOWLEDGMENTS}

The authors gratefully thank to the Vicerrectoría de Investigaciones e Interacción Social - VIIS of the Universidad de Nariño for the financial aids, and to Manfred Ricardo Palacios, for his valuable contributions to the manuscript.

Conflict of interests: The authors declare no conflict of interests.

\section{BIBLIOGRAPHICAL REFERENCES}

Acero-Nitola, A. M.; Cortés-Pérez, F. (2014). Propagación de especies nativas con potencial para restauración ecológica en la microcuenca río La Vega, TunjaBoyacá. Revista de La Academia Colombiana de Ciencias Exactas, Físicas y Naturales. 38(147): 195205. doi: https://doi.org/10.18257/raccefyn.76

Aguilar, M.; Vanegas, S. (2009). Viveros-Una experiencia comunitaria en el páramo de Rabanal. Recovered from http://www.humboldt.org.co/es/i2d/item/368viveros-una-experiencia-comunitaria-en-el-paramode-rabanal

Bacca, A.P.; Burbano, M. D. (2018). Restauración ecológica de disturbios antrópicos presentes en la zona alto andina. Revista de Ciencias Agrícolas. 35(2): 36-50. doi: https://doi.org/10.22267/rcia.183502.90

Barrett-Lennard, E. G.; Norman, H. C.; Dixon, K. (2016). Improving saltland revegetation through understanding "recruitment niche": potential lessons for ecological restoration in extreme environments. Restoration Ecology. 24: 591-597.

Baskin, C.C.; Baskin, J.M. (2014). Seeds: Ecology, biogeography and evolution of dormancy and germination. New York: Academic Press.

Cárdenas-Burgos, C. A.; Araque-Barrera, J.; BohorquezQuintero, M.A.; Hernández-Herrera, Y.; PachecoMaldonado, J. C. (2019). Propagación in vitro de Bucquetia glutinosa, especie endémica de los Paramos colombianos. Rodriguésia. 70(e00682018): 1-11. doi: https://doi.org/10.1590/21757860201970057

Courtis, A. C. (2013). Germinación de semillas, cátedra e fisiología vegetal. http://exa.unne.edu.ar/biologia/ fisiologia.vegetal/GuiadeestudioGerminaci on.pdf
Dayrell, R.L.C.; Arruda, A.J.; Buisson, E.; Silveira, F.A. (2016). Overcoming challenges on using native seeds for restoration of megadiverse resource-poor environments: a reply to Madsen et al. Restoration Ecology. 24(6): 710-713. doi:https://doi.org/10.1111/ rec.12450

Di Sacco, A.; Way, M.; Leon Lobos, P.; Suarez Ballesteros, C. I. (2018). Manual de recolección, procesamiento y almacenamiento de semillas de plantas silvestres. La Serena, Chile: Instituto de Investigaciones Agropecuarias, Centro Regional de Investigación Intihuasi. 63p.

Díaz, B.; Velásquez, L. (2015). Análisis de captura de carbono en seis especies das con fines de restauración en el Parque Ecológico La Poma (PEP) - Sabana de Bogotá - Colombia. Revista Mutis. 5(2): 51-59. doi: $10.21789 / 22561498.1072$

Espitia, M.; Cardona, C.; Araméndiz, H. (2016). Seed Germination Tests of Native Forest Species of Cordoba, Colombia in Laboratory and Greenhouse. Rev. U.D.C.A Act. \& Div.Cient. 19(2): 307-315.

Espitia, M.; Cardona, C.; Campo, R.; Araméndiz, H.; Correa, E. (2017). Contribución al conocimiento de las semillas de cinco especies forestales nativas y dos exóticas de Córdoba, Colombia. Cordoba: FORCARIBE - Universidad de Cordoba.

Espitia-Camacho, M.; Araméndiz-Tatis, H.; CardonaAyala, C. (2018). Biométricas del fruto y semillas en genetic parameters of fruit and seed biometric characteristics in Pachira aquatica Aubl . Rev. U. D. C. A. Act \& Div. Cient. 21(1): 33-42. doi: https://doi. org/10.31910/rudca.v21.n1.2018.660

Guerra, G.; Montoya, G.; Martínez, E.; Giraldo, J. (2014). Viveros de Especies Nativas para la zona cafetera de Colombia. Bogotá: Federación Nacional de Cafeteros de Colombia. 38p.

Hernández-Pineda, L.; Roa-Casas, 0.; Cortés-Pérez, F. (2014). Crecimiento de Baccharis macrantha y Viburnum triphyllum, dos especies nativas útiles en restauración ecológica, plantadas en un pastizal andino (Boyacá, Colombia). Biota Colombiana. 15(2): 25-38.

IDEAM - Instituto de Hidrología, Meteorología y Estudios Ambientales. (2018). Datos climatológicos estación Botana. Pasto, Colombia. Recovered from http:// www.ideam.gov.co/ 
Lazos-Monterrosa, F.; Orantes-García, C.; FarreraSarmiento, 0.; Verdugo-Valdez, A.; Sánchez-Cortés, M.; Ruíz-Meza, L. Resumen. (2015). Evaluación de la viabilidad y germinación de tempisque [Sideroxylon capiri (A.DC.) Pittier Sapotaceae]. Revista Internacional de Boánica Experimental. 84: 138-143.

Mancipe-Murillo, C.; Calderón-Hernández, M.; PérezMartínez, L. V. (2018). Evaluación de viabilidad de semillas de 17 especies tropicales altoandinas por la prueba de germinación y la prueba de tetrazolio. Caldasia. 40(2): 366-382. doi: https://doi. org/10.15446/caldasia.v40n2.68251

Melissa, A. H.; Torres, G. A. M. (2016). Caracterización florística de unbosque alto andino en elparque nacional naturalpuracé, Cauca, Colombia. Boletin Cientifico Del Centro de Museos. 20(1): 27-39. doi: https://doi.org/10.17151/bccm.2016.20.1.3

Oliva, M.; Oliva, C.; Rojas, D.; Oliva, M.; Morales, A. (2015). Botanical identification of native species most important of dairy basins Molinopampa, Pomacochas and Leymebamba, Amazonas, Peru. Scientia Agropecuaria. 6(2): 125-129. doi: https:// doi.org/10.17268/sci.agropecu.2015.02.05

Palomeque, X.; Maza, A.; Iñamagua, J. P.; Gunter, S. (2017). Intraspecific Variability in Seed Quality of Native Tree Species in Mountain Forests in Southern Ecuador: Implications for Forest Restoration Intraspecific Variability in Seed Quality of Native Tree Species in Mountain Forests in Southern Ecuador: Impli. Revista de Ciencias Ambientales. 51(2): 52-72. doi: https://doi.org/10.15359/rca.51-2.3

Quintero, E.; Benavides, A.M.; Moreno, N.; GonzalezCaro, S. (2017). Bosques Andinos, estado actual y retos para su conservación en Antioquia. 1 Ed. Medellín, Colombia: Fundación Jardín Botánico de Medellín Joaquín Antonio UribePrograma Bosques Andinos (COSUDE). $542 \mathrm{p}$.

Romero, D. (2015). Evaluación a la efectividad de sustratos en el desarrollo vegetativo de cinco especies arbóreas nativas de la inspección de San Francisco. Recovered from https://repository.unad. edu.co/handle/10596/6171

Sánchez, J.A.; Pernús, M.; Torres-Arias, Y.; Furrazola, E.; Oviedo, R.; Álvarez, J.C. (2018a) Características regenerativas de árboles tropicales para la restauración ecológica de ecosistemas limítrofes al manglar. Acta Botánica Cubana. 217: 170-188
Sánchez, J.; Montejo, L.; Pernús, M. (2015). Germinación de nuestras semillas: factor de éxito en la restauración ecológica. La Habana: In Instituto de Ecología y Sistemática Agencia de Medio Ambiente, CITMA.

Sánchez, J.; Pernus, M.; Torres-Arias, Y.; Barrios, D.; Dupuig, Y. (2019). Germination ecology of seeds the tropical and subtropical zones, Cuba View project Current and future potential distribution of the flora and fauna of Cuba: exploring the effects of climate change on terrestrial biota View project. Acta Botánica Cubana. 218(2): 77-108. doi: http:// org/0000-0002-7118-8608

Sánchez, J.; Pernús, M.; Echeverría, R.; Martinez, C. (2018b). Clases de dormancia en semillas de especies arbóreas útiles en la medicina tradicional cubana / Seed dormancy classes of useful tree species in traditional Cuban medicine medicina tradicional cubana Seed dormancy classes of useful tree species in traditio. Acta Botánica Cubana. 217(3): 193-204.

Sánchez, J.A.; Furrazola, E. (2018). Ecotecnologías para la restauración ecológica: los tratamientos de semillas y las micorrizas. La Habana: Editorial AMA.

Siura, S.; Moreno, S. (2016). Sustratos para propagación y siembra en invernaderos. Recovered from http://www.lamolina.edu.pe/ hortalizas/Ense\%C3\%B1anza/Clases\%20PROPA/ SPP.4.SUSTRATOS.pdf

Tomášková, I.; Vítámvás, J.; Korecký, J. (2014). Testing of germination of spruce, pine and larch seed after 10 years from collection - Short communication. Journal of Forest Science. 60 (12): 540-543.

Toro, J. (2010). Árboles de las Montañas de Antioquia. In Universidad Nacional de Colombia,Instituto de Ciencias Naturales y Ecología (Corporacin). Recovered from http://www.corantioquia.gov. co/SiteAssets/Lists/AdministrarContenidos/ EditForm/ArbolesWeb.pdf

Torres, J.; Medina, H.; Pinilla, H.; Córdoba, E.; Martínez, M. (2017). Propagación en vivero de la especie forestal Dipteryx oleífera Benth mediante semillas. Revista Politecnica. 13(24): 19-26.

Zar, J. (2010). Biostatistical Analysis. 5th Edition. Upper Saddle River: Prentice-Hall/Pearson. 944p. 